ISSN: 2689-9418

Volume 4, Issue 3, 2021 (pp. 54-73)

www.abjournals.org

\title{
KNOWLEDGE, PERCEPTION AND EXPOSURE RISK TO PASSIVE SMOKING AMONG IN-SCHOOL ADOLESCENTS IN IBADAN SOUTHEAST LOCAL GOVERNMENT AREA NIGERIA
}

\section{Adediji Funmilayo D. ${ }^{1 *}$, Professor Adelere E. Adeniran², Professor Dangana Jonathan ${ }^{2}$}

Department of Public Health, School of Public and Allied Health, Babcock University, IlishanRemo, Ogun State, Nigeria.

${ }^{1 *}$ Correspondence Author E-mail: adedijidfunmilayo@yahoo.com; Tel no: +23481500488

${ }^{2}$ Email: adeniranad@babcock.edu.ng

${ }^{3}$ Email: danganajonathanj@babcock.edu.ng

Cite this article:

Adediji F.D., Adelere E.A., Dangana J. (2021),

Knowledge, Perception and Exposure Risk to Passive Smoking Among In-School Adolescents in Ibadan Southeast Local Government Area Nigeria. African Journal of Health, Nursing and Midwifery 4(3), 54-73. DOI: 10.52589/AJHNMBETJPAJB.

\section{Manuscript History}

Received: 10 May 2021

Accepted: 31 May 2021

Published: 12 June 2021

Copyright $\odot 2020$ The Author(s). This is an Open Access article distributed under the terms of Creative Commons Attribution-NonCommercialNoDerivatives 4.0 International (CC BY-NC-ND 4.0), which permits anyone to share, use, reproduce and redistribute in any medium, provided the original author and source are credited.
ABSTRACT: Passive smoke contains more than 7,000 chemicals, including hundreds that are toxic and about 70 that can cause cancer. This is because the smoke that burns off the end of a cigar or cigarette contains more harmful substances (tar, carbon monoxide, nicotine, among others) than the smoke inhaled by the smoker. The study investigated the determinants knowledge, perception and exposure risk to passive smoking among in-school Adolescents in Ibadan Southeast Local Government Area, Nigeria. The study adopted a cross-sectional survey design. Multi stage sampling techniques were used to select four hundred and ten participants (414) among in-school Adolescents in Ibadan Southeast Local Government Area, Nigeria. The instrument was a self-report questionnaire to collect data in the study and was subjected to validation. Obtained data was analyzed using descriptive statistics of frequency and percentages. Also, correlation analyses were used to test the hypothesis at 95\% confidence level $(\alpha=0.05)$. Three research questions and two research hypotheses were tested in the study. The results showed that the mean age was $17.05 \pm 1.39$ years. The result revealed that the majority of the participants 337(82.2\%) had poor knowledge about passive smoking, while 73(17.8\%) of the respondents had good knowledge about passive smoking. Also, the result revealed that the majority of the participants 165(40.2\%) reported low exposure risk of passive smoking. Correlation analyses show that there is a significant relationship between adolescents' knowledge and exposure risk to passive smoking among in-school adolescents in Ibadan southeast local government area $(r=0.22 ; p=0.000)$. There is also a significant relationship between perception and exposure risk to passive smoking among in-school adolescents in Ibadan south east local government area $(r=0.13 ; p=0.009)$. The study therefore concluded and recommended that training programmers' should be provided to increase the adolescents' awareness, change their perceptions, increase their ability to protect themselves and help to have a smoke-free environment.

KEYWORDS: Knowledge, Perception, Exposure Risk, Passive Smoking And Adolescents 


\section{INTRODUCTION}

Passive smoking also known as secondhand smoke (SHS), or environmental tobacco smoke (ETS), is the inhalation of smoke, by persons other than the intended active smoker. It occurs when tobacco smoke enters an environment, causing its inhalation by people within that environment. Passive smoking is a growing public health problem worldwide, especially in developing countries like Nigeria undergoing rapid socioeconomic and technological development characterized by a transition from traditional to Western lifestyles (WHP 2016; Desalu, Onyedum, Adewole, \& Fawibe, Salami, 2011). Passive smoke is a mixture of gases and fine particles that include smoke from a burning cigarette, cigar, or pipe tip, smoke that had been exhaled (breathed out) by someone who smokes (National Toxicology Program, 2011). Passive smoke had also been reported as one of the most important and most widespread exposures in the indoor environment.

Smoking behaviour as a harmful trend among adolescents and young adults has increased over the last two decades. Many children and adolescents are at the risk of "second-hand" smoking at home due to their exposure to parents' or siblings' smoking. These second hand smokers are called "passive smokers" and are at risk of several health complications like cardiometabolic risk factors.

Tobacco smoking remains a major public health concern particularly among young people (Odukoya, Odeyemi, \& Oyeyemi, 2013). It is the leading preventable cause of mortality and over five million people die globally from the effects of tobacco every year. Every eight seconds someone, somewhere in the world, dies as a result of using tobacco (Iloh, \& Collins, 2017).

According to the World Health Organization (WHO) it is estimated that 1.1 billion people, representing a third of the world population above the age of 15 years, use tobacco, principally in the form of the cigarettes and of these, 700 million of them being males live in developing countries. While smoking rates have been on the decline in the developed countries, they have however been on the high side in the developing countries and it has increased by as much as $50 \%$, especially in Asia and in the Pacific region. Over the last decade about four million deaths occurred annually as a result of about a $50 \%$ increase in the rate of smoking cigarettes in developing countries. In Europe, an estimate of $26 \%$ of people aged 15 years and above approximately 100 million people smoke on a daily basis (Action on smoking and health, 2014).

Passive smoke contains more than 7,000 chemicals, including hundreds that are toxic and about 70 that can cause cancer. The explanation is that, the smoke that burns off the end of a cigar or cigarette contains more harmful substances (tar, carbon monoxide, nicotine, among others) than the smoke inhaled by the smoker. Exposure to passive smoke is widely recognized as a significant cause of short-term and long-term health effects with particular concern for the health of vulnerable groups, particularly children (Adejuwon, 2009; Onyeonoro, Chukwuonye, $\&$ Madukwe, 2016). There is also evidence linking exposure to passive smoke with various health conditions such as lung cancer, cardiovascular diseases, respiratory conditions, and obstetric complications (Centers for Disease Control and Prevention, 2016).

As the global prevalence of smoking increases so does the health hazards and harm associated with exposure to passive smoke increases with implications for the family and community 
health in Nigeria and other parts of the world such as India, Canada, Spain, and New Zealand. Globally, more than a third of the adult world population is exposed to passive smoke, and passive smoke was responsible for 600,000 deaths annually contributing to $1 \%$ of global burden of diseases (Eid, Selim, Ahmed, \& El-Sayed, 2015). A considerable number of Nigerians are exposed to secondhand smoke (SHS). It has been more reported that more than two million non-smoking adults are exposed to secondhand smoke at home $(6.6 \%)$, in the workplace (16.2\% of adults who work indoors), and in public places (27.6\% of adults who visited restaurants, $16.4 \%$ in government buildings, and $9 \%$ in public transportation (Federal Ministry of Health 2014). Awareness of the adverse health effects of SHS exposure is an especially important factor shaping public attitudes towards smoke-free policies (Desalu, Cajetan, Adewole, Ademola, Fawibe, \& Salami, 2011) Research indicates that increased knowledge about the harmfulness of SHS is associated with greater efforts to minimize exposure (Ibama, 2017) reduced SHS exposure among both smokers and non-smokers (WHO, 2009), and adoption of smoke-free home rules (Malek, Cushman, Lackland, Howard, \& McClure, 2015; Wipfli HL, \&Samet, 2011). Increased awareness of the adverse health effects of SHS exposure is also associated with lower smoking initiation among youth (Tan, \& Glantz, 2014) and more favorable attitudes toward smoke-free environments [Ajzen, \& Fishbein, 1980; Desalu, Cajetan, Adewole, Ademola, Fawibe, \& Salami, 2011].

Residents who have very poor knowledge of passive smoking could hold a positive perception toward passive smoking, such residents could see benefit in passive smoking because of his limited understanding of the danger inherited in passive smoking,

Such residents could likely have positive attitudes and ideas such as staying where a smoker is smoking cigarettes or tobacco, or feel good when a smoker is smoking cigarettes. Residents who also hold a good knowledge about passive smoking could likely have a negative attitude toward passive smoking. The kind of knowledge could inform the type of attitude a resident will have toward passive smoking which invariably will determine the level of exposure to passive smoking. Residents who hold low knowledge toward passive smoking could likely have a positive attitude which invariably could increase their level of exposure to passive smoking. It is against this background that the researchers examine the knowledge, perception and level of exposure of passive smoking among residents in Ibadan Southeast local government area of Oyo state, Nigeria.

Worldwide, it is documented that more than half a million non-smokers die from passive smoking however, the burden of tobacco related morbidity and mortality is considerably higher in developing countries (Malek, Cushman, Lackland, Howard \& McClure, 2015).

In a developing country like Nigeria, the problem of passive smoking is so challenging that it constitutes a major threat to the health and wellbeing of non-smokers in Nigeria (Wipfli, \& Samet, 2011). These health challenges have also been associated with increased morbidity in adults and children. Studies such as Iloh, and Collins (2017); Olufemi et.al., 2011; Ibama, (2017) have study passive smoking among different population but the role of exposure to passive smoking among residents especially in Ibadan Southeast Local Government Area, Nigeria is relatively scarce in the literature. Hence the gap this study hopes to fill. 
African Journal of Health, Nursing and Midwifery

ISSN: 2689-9418

Volume 4, Issue 3, 2021 (pp. 54-73)

www.abjournals.org

\section{MATERIALS AND METHODS}

\section{Research Design}

This study employed cross-sectional survey using expos-facto design, this is because these variables of interest (knowledge, perception and exposure risk to passive smoking) had already happened or occurred in nature prior to the commencement of the study.

\section{Description of the Study Area}

The study was carried out among in-school adolescents Ibadan South-East Local Government Area in Oyo State, Nigeria (Figure 3). Its headquarters are at Mapo Hall. It has an area of 17 $\mathrm{km} 2$ and a population of 266,046 at the 2006 census.

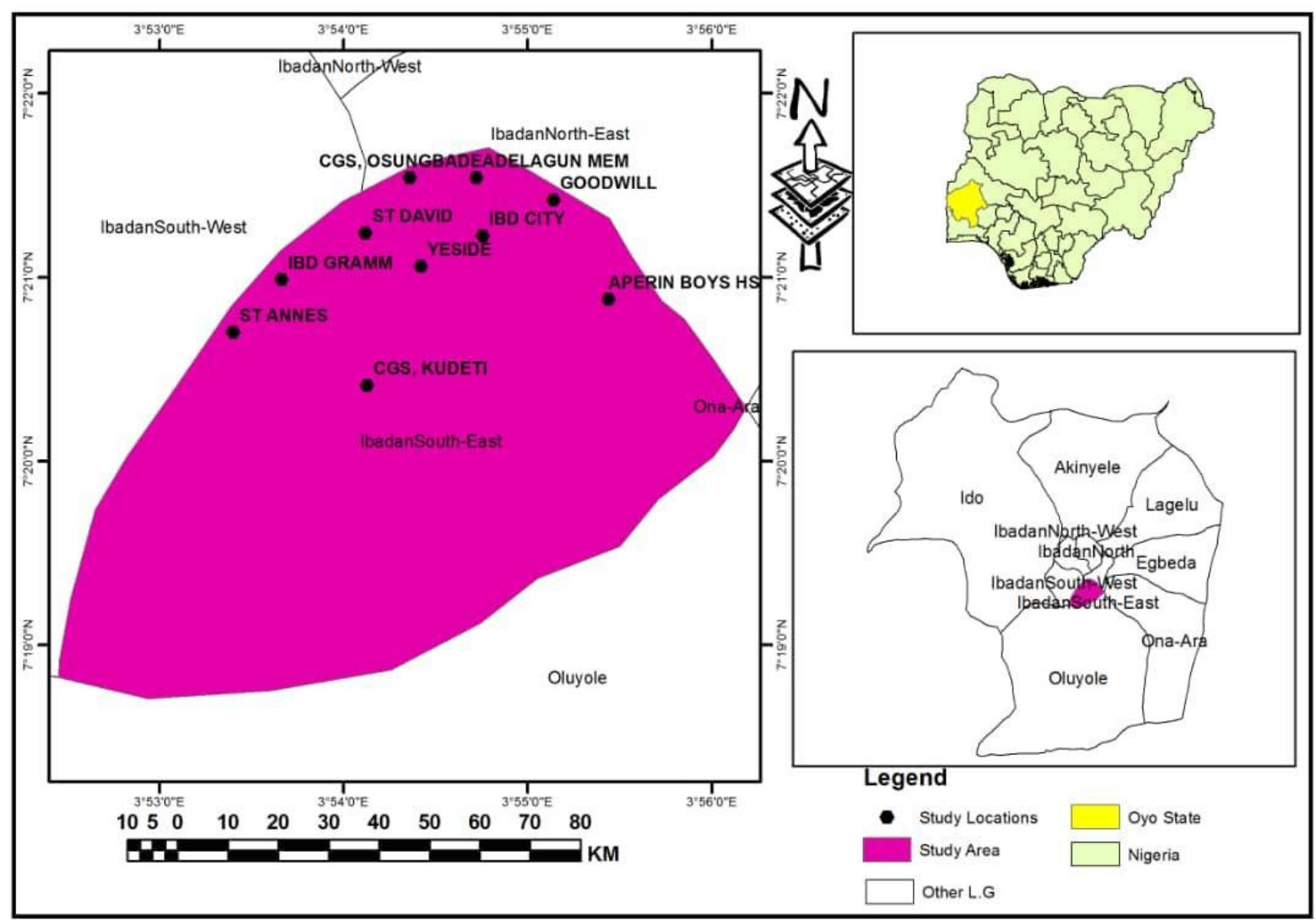

Figure 1: Map Showing Ibadan South East Local Government Area

\section{Study Population}

The study population consists of in-school adolescents in some selected public secondary schools, who have been in Ibadan South East Local Government Area for upwards of a year and given informed consent were recruited to participate in the study. 
African Journal of Health, Nursing and Midwifery

ISSN: 2689-9418

Volume 4, Issue 3, 2021 (pp. 54-73)

www.abjournals.org

\section{Inclusion criteria}

Be a Nigeria from any tribe and must be attending public secondary schools in Ibadan SouthEast Local Government from SS1 to SS3

\section{Exclusion criteria}

Teachers, non-teaching staff, principal, vice principal

\section{Sample Size Determination:}

Participants for the study were selected from some selected public secondary schools in Ibadan South East Local Government in Oyo State. The sample size was calculated using the following sample size calculation method.

A prevalence rate of secondhand smoking was obtained from a study on the Prevalence and factors associated with secondhand smoke exposure among Malaysian adolescents. The study was carried out in 2019.

$\mathrm{N}=$ minimum sample size

$=\frac{\mathrm{Z}^{2} \mathrm{pq} \mathrm{Z}^{2} \mathrm{pq}}{\mathrm{d}^{2} \mathrm{~d}^{2}}$

$\mathrm{Z}=$ confidence interval at $95 \%(1.96)$

$\mathrm{p}=$ prevalence of previous study $=41.5$ (which is 0.415 in percentage) (Ghazali et.al.,)

$q=1-P$

$\mathrm{d}=$ precision $($ acceptance margin of error $=0.05$

$q=1-(0.415)=0.585$

$\mathrm{N}=\frac{(1.96)^{2} \times(0.415) \times(0.585)(1.96)^{2} \times(0.415) \times(0.585)}{0.05^{2}}$

$\mathrm{N}=3.84 \times 0.415 \times 0.5853 .84 \times 0.415 \times 0.585$

0.0025

0.0025

$\mathrm{N}=\frac{0.9322560 .932256}{0.0025 \quad 0.0025}$

$\mathrm{N}=372.90$

$\mathrm{N} \approx 373 \approx 373$ 
To cater for $10 \%$ attrition rate

$\begin{aligned} \mathrm{n} & =\frac{\mathrm{n}}{1-\mathrm{NR}}, \mathrm{NR}=\text { Non-response rate (10\%) } \\ \mathrm{n} & =\frac{373}{1-0.1} \\ \mathrm{n} & =\frac{373}{0.9} \\ \mathrm{n} & =414\end{aligned}$

\section{Data Collection Instrument}

\section{SECTION A: Consists of socio-demographic variables}

Relevant socio-demographic information /characteristics of the participant include: age, gender, Class, religion and ethnicity.

SECTION B: This section measured knowledge of the participant as regards passive smoking. This study adopted the Questionnaire developed by Kurtz, Contreras and Booth, (2002): This questionnaire contained six (6) items the scale was in the form of a 5-point Likert response scale ranging from $(1=$ strongly agree; $2=$ agree; $3=$ undecided; $4=$ disagree; $5=$ strongly disagree). With a possible range of 6-30 points. The scoring method applied indicates that higher scores describe more accurate or better knowledge about SHS. The Cronbach alpha reported by the author $(0.90)$ and $(0.80)$ reveals a good internal consistency of the scale.

SECTION C \& D: These sections measured perception and exposure risk of the participant to the passive smoking. The Avoidance of SHS Exposure Scale developed by Martinelli was adopted. This scale included 19 items that assessed the participants' efforts to prevent SHS exposure. This scale was in the form of a 4 -point Likert response scale $(1=$ almost always true; 2 = usually true, $3=$ usually not true; and $4=$ almost never true). The author reported a Cronbach alpha of 0.70 which shows a good internal consistency of the scale.

\section{Sampling Technique:}

The study adopted a multistage sampling technique in the process of selection and collection of data. Simple random sampling which was used to select the school for the survey in Ibadan South East Local Government.

Out of the twenty-six (26) schools in the local Government, ten (10) public secondary schools were randomly selected using balloting. Also, Accidental Sampling Techniques was used to select the participants who gave their consent to participate in the study and meet the inclusion criteria. 


\section{Validity and Reliability}

\section{Validity}

In order to ensure validity of the questionnaire, a wide range of literature on related studies was reviewed and variables of interest were gathered from the literature reviewed. These variables were used to construct the questionnaire for the study in line with the conceptual framework. My supervisor and experts in public health were given drafts of the questionnaire to examine its relevance, appropriateness and adequacy.

\section{Reliability}

The instrument was pretested using a sample of 10 percent of the study sample size, from a similar study population but not the actual study population. Findings from the pre-test were used to scrutinize and reset the items of the instrument for necessary adjustments before the main administration of the instrument to the target population. The Cronbach's Alpha coefficient analysis was used to test internal consistency of the instrument to confirm its reliability. The following Cronbach alpha coefficients were obtained after a pilot study; knowledge (0.64) and perception (0.74), risk of exposure (0.73).

\section{Data collection procedure}

The study was a questionnaire driven survey and was administered to the respondents in their various schools. Research assistant who is fluent in speaking both English and Yoruba language was recruited in the collection of the data for the study. The research assistant was adequately trained on administering the questionnaire. The researcher monitored the data collection process so as to avoid errors.

\section{Data management and Data analysis}

Data collected was subjected to statistical analysis starting with the data entry and followed by analyzing the research hypotheses. Statistical Package for Social Sciences version 23 (SPSS 23) was used for the data entry and analysis. Descriptive statistics such as frequency counts, percentage, mean and standard deviation were calculated to explain and describe the demographic information while inferential statistics of correlation analysis were used to analyse the hypotheses of the study.

\section{Ethical Considerations}

Approval for this study was obtained from Babcock University Health Research Ethical Committee (BUHREC). Permission and participants' consent was sorted from the local government authorities and the schools authorities used for the study. Consent of the participants was sought, after letting them know the purpose of the study, its importance and benefits to their health and education. The students were informed about measures put in place to ensure confidentiality throughout the study. Participation in the study was voluntary and participants were given the option to withdraw from the study at any time they wish. 


\section{RESULTS}

A total of four hundred and fourteen questionnaires were prepared and distributed to the respondents and four hundred and ten were returned for statistical analysis.

\section{Demographic Characteristics of Respondents}

The respondent's age ranged from 12 to 20 years with a mean of $17.08 \pm 1.39$ years. It was revealed that $122(29.8 \%$ ) were between $12-16$ years old, while $288(70.2 \%)$ were between 17 20 years of age. Results on gender distribution of respondents shows that 226(55.1\%) were male, while $184(44.9 \%)$ were female.

\section{Respondents Level of Knowledge of passive smoking}

The respondents' level of knowledge of passive smoking which showed the total mean score of $15.58 \pm 4.78$. The result revealed that majority of the participants $337(82.2 \%)$ had poor knowledge about passive smoking, while small percent $73(17.8 \%)$ of the respondents had good knowledge about passive smoking.

\section{Respondents' perception about passive smoking}

the respondents' perception about passive smoking which showed the total mean score of 12.57 \pm 4.62 .The result revealed that majority of the participants $368(89.8 \%$ ) had poor perception about passive smoking, while $42(10.2 \%)$ of the respondents had good perception about passive smoking.

\section{Respondents' level of Exposure risk of passive smoking among in-school Adolescents}

The respondents' level of exposure risk of passive smoking with a total mean score of $38.72 \pm$ 7.57 The result revealed that 165(40.2\%) of the respondents reported low exposure risk of passive smoking, while larger percent 245(59.8\%)had high level of exposure risk of passive smoking.

Table 4.1: Distribution of respondents based on demographic characteristics

\begin{tabular}{llcc}
\hline \multicolumn{1}{c}{ Variables } & \multicolumn{1}{c}{$\mathbf{N = 4 1 0}$} & & \\
\hline Age in years $(\mathrm{m}=17.05$ & Options & Frequency & Percent \\
$\pm 1.39)$ & 13-15 years & 122 & 29.8 \\
& 16-19 years & 288 & 70.2 \\
Sex & Male & & \\
& Female & 226 & 55.1 \\
& & 184 & 44.9 \\
Class & SSS1 & & \\
& SSS2 & 22 & 5.4 \\
& SSS3 & 156 & 38.0 \\
& JSS3 & 228 & 55.6 \\
& & & 1.0 \\
\cline { 2 - 4 } & & & \\
\end{tabular}


African Journal of Health, Nursing and Midwifery

ISSN: 2689-9418

Volume 4, Issue 3, 2021 (pp. 54-73)

\begin{tabular}{llcc}
\hline Religion & Christianity & 241 & 58.8 \\
& Islam & 169 & 41.2 \\
& & & \\
\hline Ethnicity & Hausa & 11 & 2.7 \\
& Igbo & 54 & 13.2 \\
& Yoruba & 345 & 84.2
\end{tabular}

Knowledge of passive smoking among in-school

Table 4:2 knowledge of passive smoking

\begin{tabular}{|c|c|c|c|}
\hline Question (N=410) & Response & Frequency & Percentage\% \\
\hline \multirow{5}{*}{$\begin{array}{l}\text { Smoke from other people Cigarettes will } \\
\text { shorten my lifespan }\end{array}$} & Strongly agree & 193 & 47.1 \\
\hline & Agree & 120 & 29.3 \\
\hline & Undecided & 25 & 6.1 \\
\hline & Disagree & 35 & 8.5 \\
\hline & Strongly disagree & 37 & 9.0 \\
\hline \multirow{5}{*}{$\begin{array}{l}\text { Smoke from other people' cigarettes is } \\
\text { harmful for me }\end{array}$} & Strongly agree & 184 & 44.9 \\
\hline & Agree & 137 & 33.4 \\
\hline & Undecided & 22 & 5.4 \\
\hline & Disagree & 27 & 6.6 \\
\hline & Strongly disagree & 40 & 9.8 \\
\hline \multirow{5}{*}{$\begin{array}{l}\text { Smoking should be banned in all public } \\
\text { places }\end{array}$} & Strongly agree & 205 & 50 \\
\hline & Agree & 119 & 29.0 \\
\hline & Undecided & 35 & 8.5 \\
\hline & Disagree & 23 & 5.8 \\
\hline & Strongly disagree & 28 & 6.8 \\
\hline \multirow{5}{*}{ SHS smoke makes my health worse } & Strongly agree & 138 & 33.7 \\
\hline & Agree & 131 & 32.0 \\
\hline & Undecided & 58 & 14.1 \\
\hline & Disagree & 39 & 9.5 \\
\hline & Strongly disagree & 44 & 10.7 \\
\hline \multirow[t]{5}{*}{ I let visitors smoke in my home } & Strongly agree & 40 & 9.8 \\
\hline & Agree & 38 & 9.3 \\
\hline & Undecided & 28 & 6.8 \\
\hline & Disagree & 113 & 27.6 \\
\hline & Strongly disagree & 191 & 46.6 \\
\hline \multirow{5}{*}{$\begin{array}{l}\text { I ask people around me to put out their } \\
\text { cigarettes }\end{array}$} & Strongly agree & 77 & 18.8 \\
\hline & Agree & 63 & 15.4 \\
\hline & Undecided & 46 & 11.2 \\
\hline & Disagree & 76 & 18.5 \\
\hline & Strongly disagree & 148 & 36.1 \\
\hline
\end{tabular}


African Journal of Health, Nursing and Midwifery

ISSN: 2689-9418

Volume 4, Issue 3, 2021 (pp. 54-73)

www.abjournals.org

Table 4.2.1 Respondents Level of Knowledge of passive smoking

\begin{tabular}{lll}
\hline & $\mathbf{N}=\mathbf{4 1 0}$ & \\
\hline & Frequency & Percentage (\%) \\
Poor & 337 & 82.2 \\
Good & 73 & 17.8 \\
\hline
\end{tabular}

Table 4.3: Perception of passive smoking among in-school Adolescents

\begin{tabular}{|c|c|c|c|}
\hline Question & Response & Frequency & Percentage \\
\hline \multirow{5}{*}{$\begin{array}{l}\text { Second Hand smoking causes low } \\
\text { birth weight }\end{array}$} & Strongly agree & 168 & 41.0 \\
\hline & Agree & 135 & 32.9 \\
\hline & Undecided & 52 & 12.7 \\
\hline & Disagree & 44 & 10.7 \\
\hline & Strongly disagree & 11 & 2.7 \\
\hline \multirow{5}{*}{$\begin{array}{l}\text { Secondhand smoking causes ear } \\
\text { infections }\end{array}$} & Strongly agree & 128 & 31.2 \\
\hline & Agree & 115 & 28.0 \\
\hline & Undecided & 73 & 17.8 \\
\hline & Disagree & 63 & 15.4 \\
\hline & Strongly disagree & 31 & 7.5 \\
\hline \multirow{5}{*}{$\begin{array}{l}\text { Secondhand smoking causes heart } \\
\text { attacks }\end{array}$} & Strongly agree & 195 & 47.6 \\
\hline & Agree & 138 & 33.7 \\
\hline & Undecided & 38 & 9.3 \\
\hline & Disagree & 21 & 5.1 \\
\hline & Strongly disagree & 17 & 4.3 \\
\hline \multirow{5}{*}{$\begin{array}{l}\text { Second hand smoking is associated } \\
\text { with crib death (SIDS) }\end{array}$} & Strongly agree & 166 & 40.5 \\
\hline & Agree & 128 & 31.2 \\
\hline & Undecided & 67 & 16.3 \\
\hline & Disagree & 22 & 5.4 \\
\hline & Strongly disagree & 27 & 6.6 \\
\hline \multirow{5}{*}{$\begin{array}{l}\text { Second Hand smoking is associated } \\
\text { with allergies in people }\end{array}$} & Strongly agree & 135 & 32.9 \\
\hline & Agree & 140 & 34.1 \\
\hline & Undecided & 70 & 17.1 \\
\hline & Disagree & 37 & 9.0 \\
\hline & Strongly disagree & 28 & 6.8 \\
\hline \multirow{5}{*}{$\begin{array}{l}\text { Secondhand smoking is associated } \\
\text { with asthma in people. }\end{array}$} & Strongly agree & 182 & 44.4 \\
\hline & Agree & 136 & 33.2 \\
\hline & Undecided & 35 & 8.5 \\
\hline & Disagree & 27 & 6.6 \\
\hline & Strongly disagree & 30 & 7.3 \\
\hline
\end{tabular}


ISSN: 2689-9418

Volume 4, Issue 3, 2021 (pp. 54-73)

Table 4.3.1 Respondents perception about passive smoking

\begin{tabular}{lll}
\hline & $\mathbf{N}=\mathbf{4 1 0}$ & \\
\hline & Frequency & Percentage (\%) \\
Poor & 368 & 89.8 \\
Good & 42 & 10.2 \\
\hline
\end{tabular}

Table 4.4.1 Respondents Level of Exposure risk to passive smoking among in-school Adolescents

\begin{tabular}{lll}
\hline & $\mathbf{N}=\mathbf{4 1 0}$ & \\
\hline & Frequency & Percentage (\%) \\
Low & 165 & 40.2 \\
High & 245 & 59.8 \\
\hline
\end{tabular}

\section{Hypotheses Testing}

The first hypothesis stated that there will be a significant relationship between knowledge and exposure risk to passive smoking among in-school adolescents in Ibadan Southeast Local Government Area. The result of the correlation analysis showed that there is a significant relationship between adolescents' knowledge and exposure risk to passive smoking among inschool adolescents in Ibadan Southeast Local Government Area $(\mathrm{r}=0.22 ; p=0.000)$. The result is presented in table 4.5

Table 4.5: Relationship between Knowledge and exposure risk to passive smoking

\begin{tabular}{lll}
\hline Variables & $\mathbf{r}$ & $\mathbf{P}$ \\
\hline Knowledge & $.22 * *$ & .000 \\
Exposure risk to passive smoking & .00 & \\
\hline
\end{tabular}

**Correlation is significant at the 0.01 level

The second hypothesis stated that there will be a significant relationship between perception and exposure risk to passive smoking among in- school adolescents in Ibadan Southeast Local Government Area. The result of the correlation analysis showed that there is a significant relationship between perception and exposure risk to passive smoking among in-school adolescents in Ibadan Southeast Local Government Area $(\mathrm{r}=0.13 ; p=0.009)$. The result is presented in table 4.6 
ISSN: 2689-9418

Volume 4, Issue 3, 2021 (pp. 54-73)

www.abjournals.org

Table 4.6: Relationship between perception and exposure risk of passive smoking

\begin{tabular}{lll}
\hline Variables & r & P \\
\hline $\begin{array}{l}\text { Perception } \\
\text { exposure risk to passive smoking }\end{array}$ & $.13^{* *}$ & \\
& & .000 \\
\hline
\end{tabular}

**Correlation is significant at the 0.01 level

\section{DISCUSSION}

The study indicates that the majority of the participants had poor knowledge about passive smoking, while a small percent of the respondents had good knowledge about passive smoking. This is a contrast with study by Mansour (2017) revealed a higher knowledge score regarding SHS health risks. Compared to the percentage of medical students with adequate knowledge in our study $(57.5 \%)$, a larger proportion $(71.7 \%)$ of medical students had adequate knowledge regarding the risks of SHS in three different medical schools in the Central, Western, and Southern regions of the kingdom.

It was also revealed from the results that the majority had poor perception about passive smoking. Given that perceptions about the harm of passive smoking exposure were higher among respondents, this could be attributable to the changing social norms related to the social acceptability of tobacco use and the increased prevalence of smoke-free environments. These findings were not consistent with studies by Center for Disease Control and Conlisk E, Proescholdbell, Pan (2006) showing that smokers are less likely to perceive that passive smoker exposure is harmful. Similarly, a Gallup poll conducted during July 2014 found that $57 \%$ of U.S. adults viewed SHS as 'very harmful' (Saad, 2014).

Also, larger percent of the respondents had high exposure risk to passive smoking among inschool adolescents. this support studies by Singh and Lal (2011); Janson (2004); Action on Smoking and Health (2014) adult parents and significant others who smoke in the presence of children have been found to have the greatest impact on young children's respiratory health, with the most common respiratory health effect being the precipitation of asthmatic conditions. Children are especially vulnerable to the health effects of secondhand smoke, according to these studies, since their bodies are still developing and they breathe more rapidly with a higher relative breathing rate, inhaling more toxins from secondhand smoke per body weight than adults.

There was a significant relationship between knowledge and exposure risk to passive smoking among in-school adolescents in Ibadan Southeast Local Government Area. This was in contrast with a study by Centers for Disease Control and Prevention, (2014) which showed that the risk of lung cancer in non-smokers exposed to secondhand smoke has increased by $20 \%-30 \%$.

Also, Tsai, Huang, Hwang, and Lee (2014) opine that the great concern in the study area was that cigarette smokers have poor knowledge of the magnitude of harm and hazards of sidestream and mainstream smokes from burning cigarettes while innocent non-smokers are not knowledgeable of the possible adverse long-term consequences of exposure to carcinogenic 
chemicals from secondhand smoke. The longer one inhales secondhand smoke from burning cigarettes, the greater the risk of developing lung cancer.

There is a significant relationship between perception and exposure risk to passive smoking among in-school adolescents in Ibadan Southeast Local Government Area. The result demonstrates that poor perception of the participants significantly relates to increase in exposure risk to passive smoking which could be damaging to the individual's health. This corroborates the study by Licht, Hyland andTravers (2013) that found that there was relationship between SHS exposure in out-door campuses and respiratory symptoms among adolescents, and found that out-door SHS exposure was positively associated with respiratory symptoms in a monotonically increasing trend.

\section{SUMMARY}

This study investigated knowledge, perception and exposure risk to passive smoking among in-school Adolescents in Ibadan Southeast Local Government Area, Nigeria. Three (3) objectives and two (2) research hypotheses were formulated and tested at 0.05 level of significance. The study adopted a cross-sectional design. Multi-stage sampling technique was used to select ten (10) public secondary schools in Ibadan Southeast Local Government Area. A total of four hundred and fourteen students participated. The questionnaire was subjected to validity with the aid of pilot study. Data was collected through self-administered questionnaires and data collected were analyzed by using descriptive statistics of frequency table, mean and inferential statistics of correlation.

The result of the findings revealed that the majority of the participants had poor knowledge about passive smoking, while a small percent of the respondents had good knowledge about passive smoking.

Larger percent of the respondents had poor perception about passive smoking with small percent of them with good perception.

In addition, most of the respondents were exposed to the risk of passive smoking in their environment.

There was a significant relationship between knowledge and exposure risk to passive smoking among in-school adolescents in Ibadan Southeast Local Government Area.

There is a significant relationship between perception and exposure risk to passive smoking among in- school adolescents in Ibadan Southeast Local Government Area.

\section{CONCLUSION}

It is recognized that the majority of the respondents had poor knowledge about passive smoking among in-school adolescents. It was also revealed that they have poor perception about passive smoking. In addition, respondents had high risk of exposure to passive smoking. There was also a relationship between knowledge and exposure risk to passive smoking. Finally, poor perception relates to exposure risk among in-school adolescents. 


\section{RECOMMENDATION}

Based on the findings of this study the following are therefore recommended;

1. In designing effective interventions aimed at reducing exposure to passive smoking among adolescents, the Federal and State Governments must target both sociodemographic and socioeconomic risk factors.

2. Health care providers at State and Local Government levels must plan and implement educational training programs taking into consideration these risk factors for the adolescents.

3. Training programs provided by the Government at all levels should increase the adolescents' awareness and knowledge, change their perception, increase their ability to protect themselves and help them to have a smoke-free environment.

4. Recognition of the harmful effects of passive smoking should be made known to the adolescents and substantially improved the health of non-smoking adolescents who lived with smoking adults by Local Government and School Health Workers

5. The Government at all levels should legislate against public smoking with severe sanction for the deterrents. This will go a long way in ensuring a smoke free society and reduce diseases associated with passive smoking.

\section{REFERENCES}

Abdullah (2014). Correlates of exposure to SHS (SHS) at home among non-smoking adults in Bangladesh: findings from the ITC Bangladesh survey. BMC Pulmonary Medicine, $14,117$.

Action on Smoking and Health (ASH) (2014). Research Report: The Health Effects of Exposure to Secondhand Smoke; March,

Adejuwon, G.A., (2009) Tobacco use and secondhand smoke as risk factors for diseases in Nigeria: Implications for collaborative research and multilevel tobacco control strategies. African Journal Medicine Science Supp, 2, 219.

Adepoju EG., Oloowokere SA.., Adeleke NA., Afolabi OT, Olajide FO, \& Aluko OO. A (2013) population based study on the prevalence of cigarette smoking and smokers' characteristics at Osogbo, Nigeria. Tob Use Insights ;6:1-5. https:// org/10.4137/TUI.S10763

Ajzen, I., \&Fishbein. M., (1980). Understanding attitudes and predicting social behaviour. Englewood Cliffs, NJ: Prentice-Hall

Al-Shaikh GK., Alzeidan RA., Mandil AM, Fayed AA, Marwa B, \& Wahabi HA. (2014). Awareness of an obstetric population about environmental tobacco smoking. J Family Community Med. ;21:17-22.

Bahiraii A, Faghihi RS, Mirmohammad AM, \&Kazem, NA. (2012). Predictors of home smoking ban in households of pregnant women. Payesh.11(4):511517. https://www.sid.ir/en/journal/.... Accessed October 1, 2018.

Becker, MH, Drachman, RH, \& Kirscht, JP (1972.). Motivations as predictors of health behavior. Health Serv Rep 87:852-862. 
ISSN: 2689-9418

Volume 4, Issue 3, 2021 (pp. 54-73)

www.abjournals.org

Bhanji, S., Andrades, M. Taj, F. \& Khuwaja, A. K. (2011). Factors related to knowledge and perception of women about smoking: a cross sectional study from a developing country. BMC Womens Health, 11-16.

Camargo Filho JC, Garcia BC, Kodama FY, Bonfim MR, Vanderlei LC, \& Ramos EM, (2011). Effects of aerobic exercise on the skeletal muscle of rats exposed to cigarette smoke. Rev Bras Med Esporte.17(6):416-9. http://dx.org/10.1590/S1517$\underline{86922011000600010}$

Cancer Research UK. What is passive smoking? Cancer Research UK Website; 2019 [updated 28 Dec 2018; cited 17 July, 2019]; Available from:

https://www.cancerresearchuk.org/aboutcancer/causes-of-cancer/smoking-andcancer/what-is-passivesmoking.

Cao S, Yang C, Gan Y, \&Lu Z. (2015). The Health Effects of Passive Smoking: An Overview of Systematic Reviews Based on Observational Epidemiological Evidence. PLoS One. 2015; 10: e0139907.

Carlos SP, Dias AS, Forgiarini Júnior LA, Patricio PD, Graciano T, \&Nesi RT. (2014). Oxidative damage induced by cigarette smoke exposure in mice: impact on lung tissue and diaphragm muscle. J Bras Pneumol.40(4):411-20. http://dx.org/10.1590/S1806$\underline{37132014000400009}$

Centers for Disease Control and Prevention (US). How tobacco smoke causes disease: the biology and behavioral basis for smoking attributable disease. Atlanta (GA): Centers for Disease Control and Prevention (US), 2010

Centers for Disease Control and Prevention, National Institute of Occupational Safety and Health. Current Intelligence Bulletin 54: Environmental Tobacco Smoke in the Workplace - Lung Cancer and Other Health Effects. Publication No. 91-108. Centers for Disease Control and Prevention, National Institute of Occupational Safety and Health. 1991.

Centers for Disease Control and Prevention. Fourth National Report on Human Exposure to Environmental Chemicals. Atlanta: U.S. Department of Health and Human Services, Centers for Disease Control and Prevention, National Center for Environmental Health; 2009. Available from: http://www.cdc.org. [Last accessed on 2016 Dec 22].

Centers for Disease Control and Prevention. Smoking \& Tobacco Use, Health Effects of Secondhand Smoke. CDC Web Site; 2018 [updated 17 Jan 2018; cited 5 Feb 2019]; Available from:https://www.cdc.gov/tobacco/data_statistics/fact_sheets/secondh

Centres for Disease Control and Prevention. Vital signs: Nonsmokers' exposure to secondhand smoke, UnitedStates, 1999-2008. MMWR Morb Mortal Wkly Rep. 2010; 59:1141-1146.

Chatman, L. M.,(2014). Influence of knowledge and attitudes on second hand smoking among rural Jamaican mothers. Birth, 31, 265-271.

Conlisk E, Proescholdbell SK, Pan WK. Support for tobacco control policies among youth in North Carolina. North Carolina Med J. 2006;67(3):175-9.

Desalu OO, Onyedum CC, Adewole OO, Fawibe AE, \& Salami AK. (2011). Secondhand smoke exposure among nonsmoking adults in two Nigerian cities. Ann AfrMed. ;10:103-11.

Desalu, O., Cajetan C. Adewole, O., Ademola E. Fawibe, E. \& Salami, K. (2011). Secondhand smoke exposure among nonsmoking adults in two Nigerian cities Annals of African Medicine Vol. 10, No. 2; 104-110. 
Desalu, O.O, Onyedum, C.C., Adewole, O.O., Fawibe, A.E., \& Salami, A.K. (2011). Second hand smoke exposure among non-smoking adults in two Nigerian cities. Annual African Med, 103-111.

Ebirim CI, Amadi AN, Abanobi OC, \& Iloh GU. (2014). The prevalence of cigarette smoking and knowledge of its health implications among adolescents in Owerri, SouthEasternNigeria. Health. ;6:1532-8.

Ehizele AO, Azodo CC, Ojehanon PI, Akhionbare O, Umoh AO, \& Adeghe HA. Prevalence of tobacco use among dental patients and their knowledge of its health effects. Nig J Clin Pract 2012;3:(1):270-275. https://10.4103/1119-3077.100619

Evans, K. A., Sims, M., Judge, K. \& Gilmore, A. (2011). Assessing the knowledge of the potential harm to others caused by second-hand smoke and its impact on protective behaviours at home. Journal of Public Health, 1-12. http://jpubhealth. oxfordjournals.org/content/early/2011/12/26/pubmed.fdr104.full.pdf+html.

Farkas AJ, Gilpin EA, White MM, Pierce JP (2000). Association between household and workplace smoking restrictions and adolescent smoking. JAMA, 284, 717-22

Federal Ministry of Health. Global Adult tobacco Survey 2012 Country report. Available at http://nigerianstat.gov.ng/pages/download/157 (accessed June 1, 2014).

Fishbein, T.,\& Ajzen, E. (1988).Understanding attitudes and predicting social behaviour. Englewood Cliffs, NJ: Prentice-Hall

Forastiere F, Lo Presti E, Agabiti N, Rapiti E, \& Perucci CA. (2002). Health impact of exposure to environmental tobacco smoke in Italy. Epidemiol Prev. 26:18-29.

Gharaibeh, H., Haddan, L., Alzyoud, S., El-Shahawy, O., Abu Baker, N. \& Umlauf, M. (2011). Knowledge, Attitudes, and Behavior in Avoiding SHS Exposure Among NonSmoking Employed Women with Higher Education in Jordan. International Journal of Environmental Research and Public Health, 8, 4207-4219.

Glantz, A. S. \& Jamieson, P. (2000). Attitudes toward secondhand smoke, smoking, quitting among young people, Journal of Pediatrics, 1 (3), 106.

Glantz, S., \& Jamieson, P. (2001). Attitudes Toward Secondhand Smoke, Smoking, and Quitting Among Young People. Pediatrics. 106. E82. 10.1542/peds.106.6.e82. To assess the impact of attitudes toward secondhand smoke among young people.

Global Adult Tobacco Survey. Exposure to Smoke: Home. GATS Website; 2019 [updated 2015; cited 18 July, 2019]; Available from: http://gatsatlas.org/pdf/mobile/index.html\#p=55.

Global Tobacco Surveillance System (GTSS), Global Adult Tobacco Survey (GATS): Core Questionnaire with Optional Questions; 2003. Available from:http://www.cdc.gov/tobacco/global/gats/manuals/pdfs/core_questionnaire_ optional_questions.pdf. [Last accessed 2016 Nov 20].

Habiba, O. (2014) Attitude and behavior: A review. Current Psychology Research and Reviews, 11 (4), 291-307.

Harrison, J. A., Mullen, P. D., \& Green, L. W. (1992). A meta-analysis of studies of the health belief model with adults. Health Education Research, 7, 107-116.

He QQ, Wong TW, \& Du L, (2011). Environmental tobacco smoke exposure and Chinese schoolchildren's respiratory health: a prospective cohort study. Am J Prev Med41:48793.

https://apps.who.int/iris/bitstream/handle/10665/65930/WHO_NCD_TFI_99.10.pdf?sequenc $\mathrm{e}=1 \&$ isAllowed $=\mathrm{y}$. 
ISSN: 2689-9418

Volume 4, Issue 3, 2021 (pp. 54-73)

www.abjournals.org

Huang, H. L., Yen, Y. Y., Lin, P. L., Chiu, C. H., Hsu, C. C., Hu, C. Y., Lin, Y. Y., Lee, C. H. \& Chen, F. L. (2012). Household SHS exposure of elementary school children in southern Taiwan and factors associated with their confidence in avoiding exposure: a cross-sectional study. BMC Public Health, 7.

Ibama, S. (2017). Case study on impact of second hand smoke on asthma and other related diseases in the human population. International Journal of Medical and Health Research, 12, 45-67.

Iloh, P., \& Collins, C. (2017). Awareness of health effects of exposure to secondhand smoke from cigarettes: A cross sectional study of never smoked adult primary care patients in Eastern Nigeria.Avicenna J Med, 7:164-70.

Janson C. (2004). The effect of passive smoking on respiratory health in children and adults. Int JTuberc Lung Dis. ;8:510-6.

Janz, N. K., \& Becker, M. H. (1984). The health belief model: A decade later. Health Education Quarterly, 11, 1-47.

Kazemi A, Ehsanpour S, \&Nekoei-Zahraei NS. (2012). A randomized trial to promote health belief and to reduce environmental tobacco smoke exposure in pregnant women. Health Educ Res.;27(1):151-159. doi:10.1093/her/cyr102

Kazemi A, Ramezanzadeh F, \& Esfahani MHN, (2013). Impact of environmental tobacco smoke exposure in women on oxidative stress in the antral follicle and assisted reproduction outcomes. J Res Med Sci. 2013;18(8):688-694.

Labib, S., Abeer, Q. \& Ahmed, A. (2013). Knowledge, attitude and practice of university students towards smoking in Irbid, Jordon. Journal of Public Health and Epidemiology, 5 (1), 29-36.

Lajunen TK, Jaakkola JJ, \&Jaakkola MS. (2014). The synergistic effect of heredity and exposure to secondhand smoke on adult-onset asthma. Retrieved fromhttp://www.ncbi.nlm.nih.gov/pubmed/23981189.

Onyeonoro UU, Ukegbu AU, Chukwuonye II, Madukwe OO, Akhimien MO, Ogah OS. (2016). Prevalence and pattern of secondhand smoking in Abia State, Nigeria. Nig J Cardiol.; 13:119-24.

Leung, LT, Ho SY, \& Wang, M.P. (2015). Exposure to secondhand smoke from neighbours and respiratory symptoms in never-smoking adolescents in Hong Kong: a crosssectional study. BMJ Open;5:e008607.

Leventhal, H., K. Glynn, \& R. Fleming. (1991). Is the smoking decision an "informed choice"? JAMA 257(24):3373.

Lewis-Esquerre, J. M., J. R. Rodrigue, \& C. W. Kahler. (2005). Development and validation of an adolescent smoking consequences questionnaire. Nicotine \& Tobacco Research $7(1): 81$.

Licht, A.S, Hyland, A., \&Travers, M.J.(2013). Secondhand smoke exposure levels in outdoor hospitality venues: a qualitative and quantitative review of the research literature. Tob Control. 22:172-9

Lustre BL, Dixon CA, Merianos AL, Gordon JS, Zhang B, \& Mahabee-Gittens EM. (2010). Assessment of tobacco smoke exposure in the pediatric emergency department. Prev Med. 2016;85:42-6.

MacNee W, \& Rahman I. (2001). Is oxidative stress central to the pathogenesis of chronic obstructive pulmonary disease? Trends Mol Med.;7(2):55-62. http://dx.org/10.1016/S1471-4914(01)01912-8 
Malek AM, Cushman M, Lackland DT, Howard G, \& McClure LA. (2015). Secondhand smoke exposure and stroke: The reasons for geographic and racial differences in stroke (REGARDS) study. Am J Prev Med;49:e8997.

McGinnis \& Foege (1993). Actual causes of death in the United States. Journal of American Medical Association, 270 (18), 2207-2212.

National Toxicology Program (2011). Report on Carcinogens, Twelfth Edition. Research Triangle Park (NC): U.S. Department of Health and Human Services, National Institute of Environmental Health Services, National Toxicology Program,.

Oberg M, Jaakkola MS, Pruss-Ustun A, Schweizer C,\& Woodward A. (2010). Second-hand smoke: Assessing the burden of disease at national and local levels. Geneva, Worldhealth Organization WHO Environmental Burden ofDisease Series, , 18.

Öberg M, Jaakkola MS, Woodward A, Peruga A, Prüss-UstünA (2011). Worldwide burden of disease from exposure tosecond-hand smoke: a retrospective analysis of data from 192 countries. Lancet, 377, 139-46.

Oberg, M., Jaakkola, M.S., Pruss-Ustun, A., Schweizer, C., \& Woodward, A. (2010). Second-hand smoke: Assessing the burden of disease at national and local levels. Geneva, World health Organization WHO Environmental Burden of Disease Series, 6, 18-23.

Obiora CC, Dim CC, Uzochukwu BS, \& Ezugwu, F.O. (2015). Cigarette smoking and perception of its advertisement among antenatal clinic attendees in referral health facilities in Enugu, Nigeria. Niger J Clin Pract. 18:80-5.

Odukoya, O, Dada, T, Olubodun, Igwilo, Y.,\&Ayo-Yusuf, T. (2016). Cigarette smoking and perception of its advertisement among antenatal clinic attendees in referral health facilities in Enugu, Nigeria. Niger J Clin Pract 18:805.

Odukoya, O.O., Odeyemi, K.O, \& Oyeyemi, A.S. (2013). Determinants of smoking initiation and susceptibility to future smoking among school-going adolescents in Lagos state, Nigeria. Asian Pac J Cancer Prev. 14, 1747-53

Olufemi, Onyedum CC, Adewole OO, Fawibe AE, \& Salami AK. (2011). Secondhand smoke exposure among non-smoking adults in two Nigerian cities. Ann Afr Med10:10311.

Onyeonoro UU, Ukegbu AU, Chukwuonye II, Madukwe OO, Akhimien MO, \& Ogah OS. (2016). Prevalence and pattern of secondhand smoking in Abia State, Nigeria. Nig J Cardiol. 13:119-24.

Onyeonoro, U.U., Chukwuonye I.I, \&Madukwe O.O. (2016). Awareness and perception of harmful effects of smoking in Abia State, Nigeria. Niger J Cardio 112:2733.

Passey ME, Longman JM, Robinson J, Wiggers J,\& Jones LL. (2017). Smoke-free homes: what are the barriers, motivators and enablers? A qualitative systematic review and thematic synthesis. BMJ Open.6(3):e010260. doi:10.1136/bmjopen-2015-010260

Redhwan, A. A, Sami, A. R. A., Thekra, H. A., Chen, R. \& Karim, A. (2011). Prevalence and associated factors of smoking among Malaysian university students. Asian Pacific Journal of Cancer Prevention, 12, 619-624.

Rosenstock, I. M. (1974). Historical origins of the health belief model. Health Education Monographs, 2, 328-335

Rudatsikira E, Abdo A, \& Muula AS. (2015). Prevalence and determinants of adolescent tobacco smoking in Addis Ababa, Ethiopia. BMC Public Health 2007;7(1):176. https:// org/10.1186/1471-2458-7-176

Saad L. Slim majority in the U.S. call secondhand smoke very harmful: Views differ between parents who smoke vs. don't smoke. The GallupOrganization. 2014. 
[http://www.gallup.com/poll/174833/smokers-continuedownplay-harm-secondhandsmoke.aspx]

Singh RJ, \& Lal PG. (2011). Second-hand smoke: A neglected public health challenge. Indian J Public Health.55:192-8

Singh RJ, \&Lal, P.G. (2011). Second-hand smoke: A neglected public health challenge. Indian J PublicHealth. ;55:192-8.

Stone E, Peters M. (2017). Young low and middle-income country (LMIC) smokersimplications for global tobacco control. Transl Lung Cancer Res.;6(suppl 1):S44-S46.

Tan, C.E, \& Glantz, S.A. (2014). Association between smokefree legislation and hospitalizations for cardiac patient.Journal of health behaviour, 34,56-78

The Health Consequences of Involuntary Exposure to Tobacco Smoke: A Report of the Surgeon General. Washington DC: United States Department of Health and Human Services, Centers for Disease Control and Prevention, Coordinating Center for Health Promotion, National Center for Chronic Disease Prevention and Health Promotion, Office on Smoking and Health; 2006. [Last accessed 2016 Nov 20]. United States Surgeon General. Available from: http://www.surgeongeneral.gov/library/second_handsmoke/ [Google Scholar]

U.S. Department of Health and Human Services. How Tobacco Smoke Causes Disease: What It Means to You. Atlanta: U.S. Department of Health and Human Services, Centers for Disease Control and Prevention, National Center for Chronic Disease Prevention and Health Promotion, Office on Smoking and Health, 2010 [accessed 2017 Jan 11].

Varnada KN. (2014). Effects of Secondhand Smoke,. Retrieved from http://www.webmd.com/smokingcessation/effects-of-secondhand-smoke.

Surgeon general's report. Effects of Secondhand Smoke, 2006-2014. From http://www.webmd.com/smokingcessation/effects-of-secondhandsmoke.

Varnada, KN. (2014). Effects of SecondhandSmoke,.Retrieved from http://www.webmd.com/smokingcessation/effects-of-secondhand-smoke.

Vasconcelos TB, Andrade KR, Castro CF, \& Bastos VP. (2015). Evaluation of mucociliary transport in trachea of guinea pigs chemically thyroidectomized, challenged and sensitized to ovalbumin [Article in Portuguese]. Rev Biocienc.21(1):109-17

Vivilaki VG, Diamanti A, \&Tzeli M, (2016) Exposure to active and passive smoking among Greek pregnant women. Tob Induc Dis.14(1):12.10.1186/s12971-016-0077-8

Vozoris N, \& Lougheed MD. (2008). Second-hand smoke exposure in Canada: Prevalence, risk factors, and association with respiratory and cardiovascular diseases. Can Respir J. 15:263-9.

Wadi, M. A. \& Al-Sharbatti, S. S.(2011). Relationship between birth weight and domestic maternal passive smoking exposure, East Mediterranean Health Journal, 17, 290-296.

WHO (2009). WHO Report on the Global Tobacco Epidemic, 2009: Implementing Smokefree Environments. World Health Organization, Geneva (2009) (http://www. who.int/tobacco/mpower/2009/en/index. html, accessed 28 October 2014)

WHO. (2019). Tobacco free initiative (TFI). www.who.int/tobacco/mpower/ en/. Published 2017. Accessed December 18,.

Wipfli HL, \& Samet JM. (2011).Secondhand smoke's worldwide disease toll. Lancet. $377: 1012$. 
Witte, M., Saunders, A.F., Samsa, G.P., L.B., Gold,D.T., Brown, J.T., Booher, P., \& Loehrer, P.J. (1993). Breast cancer screening in older women: Practices and barriers reported by primary care physicians. Journal of Geriatric Society, 39(1): 22-29.

World Health Organization. (2008). WHO Report on the Global Tobacco Epidemic.

Switzerland, Geneva: World Health Organization. Available from: http://www.who.int/tobacco/mpower/mpower_report_full_2008.pdf. [Last accessed on 2016 May 25].

World Health Organization. Global Health Observatory (GHO) data. WHO Website; 2019 [updated 2019; cited 17 July 2019]; Available from: https://www.who.int/gho/tobacco/use/en/

World Health Organization. Global Health Observatory data repository. WHO Website; 2019 [updated 2016; cited 17 July 2019]; Available from: http://apps.who.int/gho/data/view.main.1805REG?lang=en

World Health Organization. History of the World Health Organization Framework Convention on Tobacco Control. Geneva: WHO, 2009.

World Health Organization. Tobacco free initiative consultation report. WHO Website; 1999 [updated 1999; cited 6 March 2019]; Available from:

World Health Organization. Tobacco. WHO Website; 2019 [updated 26 July 2019; cited 3 Aug 2019]; Available from: https://www.who.int/news-room/fact-sheets/detail/tobacco.

Yang L, Tong EK, Mao Z, \& Hu TW. (2010). Exposure to secondhand smoke and associated factors among non-smoking pregnant women with smoking husbands in Sichuan province, China. Acta ObstetGynecol Scand. 89(4):549-557. 10.3109/00016341003713851 